\title{
Accounting
}

\section{Investment attractiveness rating and factors affecting}

\author{
Irany Windhyastiti ${ }^{\mathrm{a}}$, Syarif Hidayatullah ${ }^{\mathrm{a}}$ and Umu Khouroh ${ }^{\mathbf{a}^{*}}$
}

\begin{tabular}{l}
${ }^{a}$ University of Merdeka Malang, Indone \\
\hline C H R O N I C L E \\
\hline Article history: \\
Received: April 28, 2020 \\
Received in revised format: \\
July 30 2020 \\
Accepted: September 25, 2020 \\
Available online: \\
September 25, 2020 \\
\hline Keywords: \\
Investment Attraction \\
Licensing System \\
Leadership \\
Rating
\end{tabular}

\section{Introduction}

According to Law No. 32 of 2004 (UU, 2004) associated with Regional Government which is a revision of Law No. 22 of 1999 concerning Regional Autonomy, regional autonomy gives regions the right to manage the own households. Regional autonomy is widely believed to be the best way to encourage regional development (Osborne \& Plastrik, 2000). The implementation of regional autonomy is expected to improve services in various sectors, mainly the public sector so that investors are interested in investing the regions. If an area has adequate infrastructure, investors will be interested in investing and the community can also carry out daily activities comfortably so that it would have an impact on increasing productivity. The increase in community productivity and the number of investors investing is expected to increase profitability which in turn will have an impact on increasing regional spending (Abimanyu, 2005). Therefore, it can be said that investment is one of the important things that drives the achievement of quality development. This is partly because investment has an influence on aggregate growth in terms of its ability to boost output and job opportunities, and it has an impact on capital formation which in the long run can increase output potential and maintain growth (Hamid, 2006). Regional investment is carried out by components of government, society, and the private sector (business world). Increased regional investment can be realized if the region has "potential" to sell. The ability of regions to sell must also be supported by a conducive climate such as security and legal certainty. Murwito (2013) believes that the Regional Government must produce regulations to trigger economic growth to attract investors. In addition, the system in government must be improved to be more effective and efficient. Long-winded procedures must be abandoned.

* Corresponding author

E-mail address: umu.khouroh@unmer.ac.id (U. Khouroh)

\begin{abstract}
This research aims to determine: 1) rating of investment attraction based on investor assessment; and 2) the factors which have significant effects on investment attraction of the city. Location research is
in Batu city Indonesia with number of samples as 65 investors. The data analysis technique of this study uses a Multiple Regression Analysis. The independent variables used in this study are: 1)
infrastructure; 2) labor availability; 3) agglomeration; 4) natural resources, 5) markets; 6) licensing system, and 7) leadership. Investment attraction is indicated with rating assessment by investors. The results show: 1) rating of Batu city investment attraction is high; and 2) licensing system and
leadership have significant influences on investment attraction. Based on the result, it is very important for a city to create a conducive climate (pro investment) to attract investors, especially in the ease of the licensing system. In addition, local governments must be able to provide positive
signals in the form of commitment for the investment development in Batu city. This is necessary since the city development process really needs investor support.
\end{abstract}


Some local governments have taken steps to attract investors, but not yet thoroughly (KPPOD, 2013). Kuncoro (2004) states several initiatives were carried out including reforming the investment service bureaucracy, building information systems on investment potential, and enhancing and provisioning physical infrastructure. The attractiveness of investment is one type of lure that is targeted at attracting a businessman to a special location. The attraction of city investment is related to the availability of resources, the ability of cities to manage them and attract new ones to benefit from other cities and ensure the development of the city (Snieskaa \& Zykiene, 2015). This attractiveness definition interprets it is a cyclical process, as an attractive city will be able to attract and retain certain target groups (tourist, investor, and new resident), where the output of the attraction will contribute, which in turn will have an impact on the outcome (Servillo, Atkinson, \& Russo, 2012). According to the some researchs description above, this study aims to examine: 1) the investment attractiveness rating of Batu city based on investors' assessments; and 2) the factors which have significant effects on the investment attraction of Batu city. The choice of Batu city as the object of research is because Batu city is one of the cities in the East Java Province of Indonesia, which is one of the potential tourist cities with a fairly high number of tourists. In 2017 , the number of tourists reached a total of $4,188,910$ tourists where 4,622 were foreign tourists. Batu city has a big target in 2025, namely the achievement of Tri Asa, namely as a competitive education center, organic agriculture center and an internationally competitive tourism center. Therefore, to help achieve these targets, investors are needed to assist the development process in Batu city.

\section{Literature review}

\subsection{Investment Appeal}

The attractiveness of investment is one type of lure that is targeted at attracting a businessman to a special location. The attraction of city investment is related to the availability of resources, the ability of cities to manage them and attract new ones so that they can benefit from other cities and ensure the development of the city (Snieskaa \& Zykiene, 2015). This attractiveness definition interprets that it is a cyclical process, as an attractive city will be able to attract and retain certain target groups (tourist, investor, and new residents), where the output of the attraction will contribute, which in turn will have an impact on the outcome (Servillo et al., 2012).

\subsection{Factors Affecting Investment Attraction}

Mcdonald and Bailly (2017) state that the characteristics of city that have the most highly value are: 1) growth potential of economy, highly skilled of workforce, and resistant of external shocks and the decrease of economic; 2) reliable connections of tranportation, both intracity and intercity (nationally and internationally), as well as a the system of tranportation that can support the economy expandation; 3) the leader of the city should pro-investment, which prioritizes a city investment, has many consistent policies, has a good profile attitudes, and has a bargaining power to the centre government; and 4) focus on delivery, responsive to planning system pro-investment, has a team with good access to expertise of investment and will help immediately when neeeded to facilitate investment. Danciu and Strat (2014) state that, foreign direct investment (FDI) in the regions of Romanian uses scores of the factor extraction for the six variables: 1) labor; 2) agglomeration; 3) infrastructure; 4) knowledge; 5) market; and 6) cost and dummy variable as a common measures determinants of location for the inflow of Foreign Direct Investment. The dependent variable shows the probability of either invest or not invest in any certain region, with the BucharestIlfov region being a group comparation. The results show that there are substantial difference of the attraction in regions of Romanian, when the initial of FDI inflows are evaluated. FDI were attracted by the potential of the regions, th accessibility of the region and the mentality of local business. In Romania, input costs and the availability of resources, and labor are factors that be an important concern by investor for investing, then all regions are more liked for the inflow of foreign investment than the area of Bucharest-Ilfov. Snieskaa and Zykiene (2015) show that, in many cases, for investment in Lithuania, the choicement of the city is effected by the accessibility and the cost of skilled workforce, price of resource and market. In line with the some results above, Global Cities Investment Monitor established several criteria of investment, namely: 1) the political stability and the juridical security; 2) the availabitity of infrastructure; 3) the availability of human resources skills; 4) the growth of economic; 5) the accessibility and size of the market; 6) salaries, tax level and living cost; 7) the availability and cost of real estate; 8) education quality; 9) life quality, 10) the quality of research and innovation; and 11) start up ecosystem (KPMG, 2018). This study uses several combination variables from the research of Kuncoro Mcdonald \& Bailly, Danciu \& Strat and the Global Cities Investment Monitor. The independent variables used in this study are: 1) infrastructure; 2) availability of labor; 3) agglomeration; 4) natural resources, 5) markets; 6) licensing system, and 7) leadership. While the dependent variable in this study is the attractiveness of investment as measured by an assessment (rating) of investment attractiveness.

\subsection{Hypothesis}

Based on the descriptions of previous studies that are relevant to this research, the hypotheses are formulated as follows:

H1: The infrastructure factor has a significant effect on investment attractiveness. 
H2: The labor availability factor has a significant effect on investment attractiveness.

H3: Agglomeration factors have a significant effect on investment attractiveness.

H4: Natural resource factors have a significant effect on the attractiveness of investment.

H5: Market factors have a significant influence on investment attractiveness.

H6: The licensing system factor has a significant effect on investment attractiveness.

H7: The leadership factor has a significant influence on investment attractiveness.

\section{Methodology}

\subsection{Research design}

This research is a case study research in Batu city, East Java. Data analysis is based on using Multiple Regression Analysis.

\subsection{Population, Samples and Sampling Techniques}

The research population includes investors who have used the Online Licensing System (OSS = Online Single Submission). The research sample consisted of 65 investors in Batu city. The sampling technique was random sampling. The respondent data can be seen in Table 1. Most of the respondents were over 40 years old (41.5\%), had a bachelor's degree (36.9\%) and high school education (29.2\%), and had businesses in the hotel / lodging sector (40\%) and culinary (30.8\%).

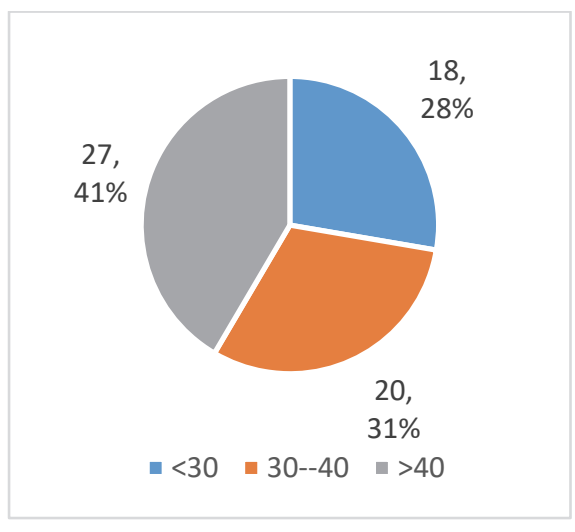

Age

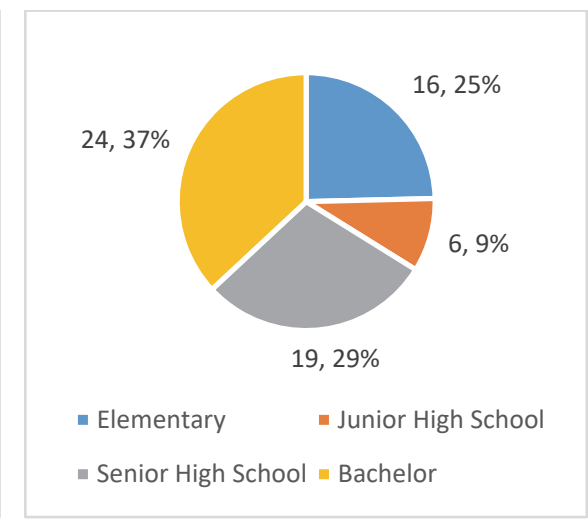

Educational background

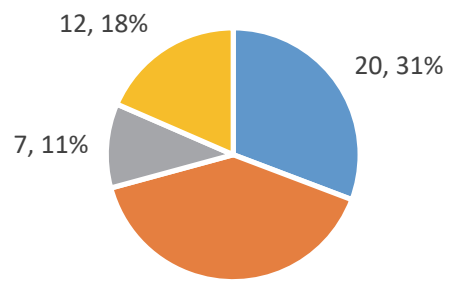

$26,40 \%$

- Culinary

- Hotel/homestay

- Tourist/entertainment place

- Others

\subsection{Operational Definition of Variables}

Fig. 1. Personal characteristics of the participants

Type of business

The dependent variable in this study is investment attractiveness as measured by the investment attractiveness rating made by investors on a rating scale of 1 to 5 . While the indicators of each independent variable used in this study can be seen in Table 1.

Table 1

Variables and Indicators of Research

\begin{tabular}{|c|c|c|}
\hline & Variables & Indicators \\
\hline \multirow[t]{7}{*}{1} & Infrastructure & Cost of public transportation \\
\hline & & Number of public transportation \\
\hline & & Road condition \\
\hline & & Number of terminal \\
\hline & & Terminal condition \\
\hline & & Completeness of facilities and infrastructure \\
\hline & & Facilities and infrastructure condition \\
\hline \multirow[t]{2}{*}{2} & Availability of labor & Cost of labor \\
\hline & & Education of labor \\
\hline \multirow[t]{3}{*}{3} & Agglomeration & Availability of industry centers \\
\hline & & Availability of industrial supporting components \\
\hline & & Availability of similar industries \\
\hline 4 & Natural Resources & Availability of raw material \\
\hline 5 & Market & Market Potential \\
\hline 6 & Business licensing process & Convenience \\
\hline \multirow[t]{3}{*}{7} & Leadership & Competence \\
\hline & & Commitment \\
\hline & & Reputation \\
\hline
\end{tabular}




\section{Analysis and interpretation}

\subsection{Analysis}

Batu city has a big target in 2025, namely the achievement of Tri Asa, namely as a competitive education center, organic agriculture center and an internationally competitive tourism center. Therefore, to help achieve these targets, investors are needed to assist the development process in Batu city. In 2016, the regional investment value in Batu city reached Rp. $1,915,000$ million (an increase of 37\% from 2015). But unfortunately in 2017 it decreased $8 \%$ to IDR 1,755,000 million. Therefore, it is important to know what affects the investment attractiveness of Batu city from an investor's point of view.

Table 2

The summary of R-Square

\begin{tabular}{lcccc}
\hline Model & $\mathrm{R}$ & $\mathrm{R}$ Square & Adjusted R Square & Std. Error of the Estimate \\
1 & $0.753^{\mathrm{a}}$ & 0.567 & 0.513 & 0.44851 \\
\hline a. Predictors: (Constant), leadership, availability of labor, natural resouces, market, infrastructure, licensing processed, agglomeration
\end{tabular}

Table 3

F and t Test

\begin{tabular}{|c|c|c|c|c|c|c|c|}
\hline \multicolumn{8}{|c|}{ ANOVA $^{a}$} \\
\hline \multicolumn{2}{|c|}{ Model } & \multirow[t]{2}{*}{ Sum of Squares } & \multicolumn{2}{|c|}{$\mathrm{df}$} & \multirow{2}{*}{$\begin{array}{l}\text { Mean Square } \\
2.142\end{array}$} & \multirow{2}{*}{$\begin{array}{l}\mathrm{F} \\
10.649\end{array}$} & \multirow{2}{*}{$\begin{array}{l}\text { Sig. } \\
.000^{\mathrm{b}}\end{array}$} \\
\hline 1 & Regression & & 14.995 & 7 & & & \\
\hline & Residual & & 11.466 & 57 & .201 & & \\
\hline & Total & & 26.462 & 64 & & & \\
\hline
\end{tabular}

a. Dependent Variable: Investment Rating

b. Predictors: (Constant), leadership, availability of labor, natural resouces, market, Infrastructure, Licensing, Agglomeration

\begin{tabular}{|c|c|c|c|c|c|}
\hline \multirow[b]{3}{*}{ Model } & \multicolumn{3}{|c|}{ Coefficients $^{\mathrm{a}}$} & \multirow[b]{3}{*}{$\mathrm{t}$} & \multirow[b]{3}{*}{ Sig. } \\
\hline & \multicolumn{2}{|c|}{ Unstandardized Coefficients } & \multirow{2}{*}{$\begin{array}{c}\text { Standardized } \\
\text { Coefficients }\end{array}$} & & \\
\hline & $\mathrm{B}$ & Std. Error & & & \\
\hline $\begin{array}{ll}1 & \text { (Constant) }\end{array}$ & -2.030 & 1.362 & & -1.490 & .142 \\
\hline Infrastructure & -.031 & .255 & -.019 & -.123 & .903 \\
\hline Availability of labor & .257 & .210 & .150 & 1.225 & .226 \\
\hline Agglomeration & .032 & .197 & .027 & .164 & .870 \\
\hline Natural resouces & -.027 & .084 & -.038 & -.321 & .750 \\
\hline Market & .145 & .111 & .170 & 1.309 & .196 \\
\hline Business Licensing Process & .855 & .376 & .311 & 2.276 & .027 \\
\hline Leadership & .364 & .174 & .310 & 2.097 & .040 \\
\hline
\end{tabular}

The results of statistical analysis in Table 3 show that the variables of infrastructure, availability of labor, agglomeration, natural resources, market potential, the licensing process and leadership contributed to the investment attractiveness rating of $51.3 \%$ (Adjusted R Square $=0.513$ ), while the remaining $48.7 \%$ is influenced by other variables such as political stability and security as well as the level of economic growth.

Based on the results in Table 4, it shows that: 1) The infrastructure factor does not have a significant effect on investment attractiveness ( $\operatorname{sig} \mathrm{t}=0.903)$, meaning $\mathrm{H} 1$ is rejected, 2) The labor availability factor does not have a significant effect on investment attractiveness ( $\operatorname{sig} \mathrm{t}=0.226)$, means $\mathrm{H} 2$ is rejected, 3) Agglomeration factors do not have a significant effect on investment attractiveness ( $\operatorname{sig} \mathrm{t}=0.870)$, meaning $\mathrm{H} 3$ is rejected, 4) Natural resource factors do not have a significant effect $(\operatorname{sig} t=0.750)$ on investment attractiveness, means H4 is rejected, 5) Market factors have no significant effect on investment attractiveness ( $\operatorname{sig} \mathrm{t}=0.196)$, meaning $\mathrm{H} 5$ is rejected, 6) The licensing system factor has a significant effect $(\operatorname{sig} t=0.027)$ on investment attractiveness, meaning H6 is accepted, and 7) The leadership factor has a significant effect $(\operatorname{sig} \mathrm{t}=0.040)$ on investment attractiveness, meaning that $\mathrm{H} 7$ is accepted. 
While the results of the respondents' assessment (65 investors) of the investment attractiveness of Batu city as a whole obtained an average value of 4.16 (on a scale of 1 to 5 rating). This rating shows a high number (close to a maximum of 5) so that it can be said that Batu city has high investment attractiveness for investors.

\subsection{Interpretation}

Based on the data analysis, infrastructure and natural resource factors have no influence on the attractiveness of investment in Batu city. This result is in line with the research conducted in Alytus city, which concludes that the availability of road and transportation infrastructure and the availability of natural resources are the basic factors as having no effect on their decision to choice Alytus city. But, that factors should be treated as 'gray' factors that are general in all investment areas, so that they do not interpret exclusivity of investment attraction to the Alytus city, but principly that factors have an effect on the decision to invest (Snieskaa \& Zykiene, 2015). The results also show that the licensing process has an influence on investment attractiveness. This is in line with the opinion of Kuncoro (2004) which states that one of the steps to attract investors is to improve the bureaucracy of investment services. Ezmale (2012) also said that one of the most important factors of city attraction for the residents in Latgale region is the quality and availability of the country and city services. The results of this study are in line with Suhendra's research results which show that pro-investment policies, including those carried out in the licensing process, can help achieve investment targets (Suhendra, 2017). In addition, this research is also in accordance with Widhayanti's research results which show that the highest score in determining the attractiveness of regional investment is apparatus and services in business licensing (Widhayanti \& Muta'ali, 2012). Regarding the condition of Batu city, in 2018 the Government of Batu city, through the One Stop Investment Service and Manpower, began to use the online single submission process which is more practical since it can be done anywhere and anytime so this system makes it very easy for investors to manage permits. If all the requirements are complete, with this system investors can complete the licensing process in approximately 2-3 hours. This online licensing system can be an investment attraction in Batu City. It's also line with the research of (Windhyastiti, Hidayatullah, Khouroh, \& Waris, 2019), said that bureaucratic system showed by the Online Single Submission (OSS) performance, has a positive and significant effect on attractiveness of investment in Batu city, Indonesia

In addition, the result which show that the leadership factor has an influence on investment attractiveness is in line with the opinion of Mcdonald \& Bailly (2017) which states that for investors, the characteristics of a city that are considered to have the highest value include city leadership which is pro-investment, which prioritizes investment, has consistent policies and attitudes, is well-known, and has a bargaining position with the central government. This result also line with reserach of Ueng, $\mathrm{Cfa}$, Lee, $\mathrm{Ph}, \&$ Gee (2016) that provides empirical evidence of the willingness of local leaders to attract outside investment to their small town, such as offering tax breaks to companies If it is related to the condition of Batu city, it can be seen that the government is indeed highly committed to the development of investment in Batu city. Batu city had collapsed with the Lapindo mud disaster in 2007, where the total of tourist visits was less than 1 (one) million people. However, the government took the initiative to persuade entrepreneurs and investors to stay in their place of business. The government then began to make various activities that could attract tourist visits such as the Batu Flower Festival, the East Java Cultural Festival, the National Paragliding Festival, the Batu Night Race, and others. The government also provides security guarantees to investors to invest their capital. During its development, investor confidence began to increase and investors began targeting Batu city as an educational tour. The target is students and families. This educational-based tourism has turned out to be able to make Batu city widely known again. Seeing the increase in the number of tourist visits, the government then began to package the Batu city Square as a tourist spot (Windhyastiti I \& Widiawati D, 2016). In 2017, Batu city has been able to increase tourists to reach 4 (four) million people.

Based on the description above, it is very important for a city to create a conducive climate (pro investment) to attract investors. This is necessary because the city development process really needs investor support. Governments have to learn "how to steer rather than row". There should be a good integration of city governance functions, with the strong of formal structure, and high levels of accountability and responsibility for elected representatives. City governance should be supported by a strong citizen organisation (Ratcliffe, n.d.). Generally, it is also important to enter city marketing in an explicit part of the city's documented of political priorities and programmes (Braun E, 2008). In addition, local governments must be able to provide positive signals in the form of high commitment to investment development in Batu city. Furthermore, if local governments are able to increase the value of investment in their regions, it will have a positive impact on increasing local revenue (Windhyastiti, Hidayatullah, \& Khouroh, 2019). 


\section{Conclusion and recommendations}

\subsection{Conclusion}

Based on data analysis, it can be concluded that: 1) the rating value of the investment attractiveness of Batu city is high (close to the maximum number on the rating scale used). This shows that in the eyes of investors, Batu city has a high investment attractiveness; and 2) the licensing system and leadership variables have a significant influence on investment attractiveness.

\subsection{Recommendations}

Based on the conclusion of the research results, it is very important for a city to create a conducive climate (pro investment) to attract investors, especially in the ease of the licensing system. In addition, local governments must be able to provide positive signals in the form of commitment to investment development in Batu city. This is necessary because the city development process really needs investor support.

\section{References}

Abimanyu, A. (2005). Format Anggaran Terpadu Menghilangkan Tumpang Tindih. Bappeko Depkeu pdf. 2-4.

Braun, E. (2008). City Marketing: Towards an integrated approach (No. EPS-2008-142-ORG).

Danciu, A. R., \& Strat, V. A. (2014). Factors influencing the choice of the foreign direct investments locations in the Romanian regions. Procedia-Social and Behavioral Sciences, 109, 870-874.

Osborne, D., \& Plastrik, P. (2000). Memangkas birokrasi: Lima strategi menuju pemerintahan wirausaha. Jakarta: Penerbit PPM..

Ezmale, S. (2012). Strategies for Enhancing Attractiveness of the Cities in Latgale Region. European Integration Studies, 6, $121-127$.

Hamid, E. S. (2006). Ekonomi Indonesia: dari Sentralisasi ke esentralisasi.

KPMG. (2018). Global Cities Investment Monitor 2013. 28.

KPPOD. (2013). Kerjasama Antar Daerah di Bidang Perdagangan sebagai Alternatif Kebijakan Peningkatan Perekonomian Daerah. KPPOD.

Kuncoro, M. (2004). Otonomi dan Pembangunan Daerah : Reformasi, Perencanaan, Strategi, dan Peluang. Jakarta: Erlangga.

Mcdonald, R., \& Bailly, A. (2017). What investors want: A guide for cities.

Ratcliffe, J. (n.d.). Competitive Cities: Five Keys to Success. Retrieved from The Challenge Network.

Servillo, L., Atkinson, R., \& Russo, A. P. (2012). Territorial attractiveness in EU urban and spatial policy: A critical review and future research agenda. European Urban and Regional Studies, 19(4), 349-365.

Snieskaa, V., \& Zykiene, I. (2015). City Attractiveness for Investment: Characteristics and Underlying Factors. Procedia Social and Behavioral Sciences.

Ueng, C. J., Cfa, P. D., Lee, C. C., Ph, D., \& Gee, N. (2016). Factors affecting foreign direct investment in a small town in America. Review of Contemporary Business Research, 5(2), 9-16.

Widhayanti, N. (2012). Persepsi Pelaku Usaha terhadap Daya Tarik Investasi di Kabupaten Nganjuk, Jawa Timur. Jurnal Bumi Indonesia, 1(1).

Windhyastiti, I., Hidayatullah, S., \& Khouroh, U. (2019). How to increase city investment attraction. International Journal of Scientific and Technology Research, 8(9).

Windhyastiti I, \& Widiawati D. (2016). Pentingnya Aspek Goverment Power Dalam Pengembangan Industri Pariwisata Daerah. Jurnal Manajemen dan Kewirausahaan. 4(1), 37.

Windhyastiti, I., Hidayatullah, S., Khouroh, U., \& Waris, A. (2019). Role of The Online Single Submission (OSS) To Increase The City Investment Attraction. 4th International Conference of Graduate School on Sustainability (ICGSS) $2019,1-6$.

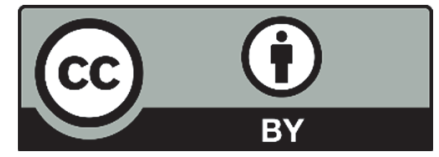

(C) 2020 by the authors; licensee Growing Science, Canada. This is an open access article distributed under the terms and conditions of the Creative Commons Attribution (CC-BY) license (http://creativecommons.org/licenses/by/4.0/). 